\title{
The Impact of Message Framing and Source Credibility on Breastfeeding Intention: A Social Marketing Approach ${ }^{\#}$
}

\author{
Ananda Sabil Hussein, ${ }^{*^{*}}$ Valerie Mannad and David Cohen ${ }^{\mathrm{b}}$ \\ ${ }^{a}$ Faculty of Economics \& Business, Universitas Brawijaya, Malang, Indonesia \\ ${ }^{b}$ Faculty of Commerce Lincoln University Canterbury, New Zealand
}

\begin{abstract}
Though highly recommended by health organizations worldwide, breastfeeding an infant from birth for a period of several months is not universal. There is thus a need to investigate appropriate and effective means to promote this breastfeeding behavior.

This study, rooted in a social marketing perspective, tests the impact of message framing and source credibility on the behavioral intention to breastfeed. A $2 \times 2$ factorial experiment was conducted in Indonesia, an especially relevant setting given that the percentage of Indonesian women who breastfeed is low compared to other countries. Two hundred and seventy nine pregnant women participated in this study. The findings of this study indicate that the interaction between message framing and source credibility has a significant effect on a person's attitude and intention to provide exclusive breastfeeding. In addition, this study finds that attitude is an essential determinant of intention.
\end{abstract}

\begin{abstract}
Abstrak: Meskipun menyusui bayi sejak lahir untuk jangka waktu tertentu sangat dianjurkan oleh berbagai organisasi kesehatan dunia, namun hal tersebut tidak universal. Oleh karena itu, perlu diadakan penelitian untuk mendapatkan cara yang tepat dan efektif untuk mempromosikan perilaku menyusui.

Penelitian ini yang berakar dalam perspektif social marketing, yang menguji dampak pesan framing dan kredibilitas sumber data terhadap niat berperilaku untuk menyusui. Percobaan dengan menggunakan desain faktorial $2 \times 2$ dilakukan di Indonesia yang sangat relevan mengingat persentase perempuan Indonesia yang menyusui lebih rendah daripada negara lain. Penelitian ini dilakukan dengan sampel data sebanyak 279 perempuan hamil yang berpartisipasi dalam penelitian ini. Temuan dari penelitian ini menunjukkan bahwa interaksi antara pesan framing dan kredibilitas sumber data memiliki pengaruh yang signifikan terhadap sikap dan niat untuk memberikan air susu ibu (ASI) eksklusif. Selain itu, penelitian ini menemukan bahwa sikap merupakan faktor penting dalam menentukan niat.
\end{abstract}

Keywords: attitude; framing; behavioral intention; breastfeeding; credibility

\# This is a part of Hussein's doctoral dissertation at Lincoln University, New Zealand.

* Corresponding author's e-mail: sabil@ub.ac.id

ISSN: $1141-1128$

http://www.gamaijb.mmugm.ac.id/ 


\section{Introduction}

The way a message is framed can have a significant effect on the result of its communication (Rothman and Salovey 1997). Message framing has been widely used in designing promotional messages, especially those seeking to influence individual behavior. Kahneman and Tversky's (1979) Prospect Theory is one basis by which the impact of message framing on behavior can be better understood. This theory explains that when presented in different ways, information can encourage an alteration of people's perspectives, preferences and actions. This is reflected in practice, where message framing strategies have been used in many health promotional messages involving both prevention and detection behaviors. To influence people to adopt prevention behavior -a behavior designed to avoid the onset of a health problem-a positively-framed message is thought to be more effective than a negatively-framed message (Rothman and Salovey 1997). However, to influence individuals to engage in detection behavior, a negatively-framed message is likely to be better than a positivelyframed message. Although this suggestion reflects the Prospect Theory's core proposition, empirical findings have been inconsistent in regards to these effects (Arora 2000; O'Keefe and Jensen 2007; Rothman et al. 1993). The inconsistent findings suggest that there is value in testing the relationship in a different setting with different behaviors from those that have previously been examined.

In addition, our incomplete knowledge on the impact of message framing on behavior suggests that further study is needed to examine the credibility of the message source as an additional variable which could moderate the impact of message framing on an individual's behavior. To date, the moderating effect of source credibility has been found in studies on the promotion of goods or services (Arora et al. 2006; Jones et al. 2004; Kumkale et al. 2010; Zhang and Buda 1999). Though examples of studies focused on the role of source credibility in social marketing programs can be found, they are relatively rare. For example, Kim and Kim's (2014) study observed the effect of message framing and source credibility on individual's attitudes and intentions about green messages provided by a hotel. While source credibility has been found to moderate the effect of framing on behavioral intention and its antecedents, no study has been found which addresses the potential interaction effect between message framing and source credibility with a particular focus on breastfeeding behavior.

Breastfeeding has been widely recognized as the perfect source of nutrition for babies for the first six months of their life. The term "exclusive breastfeeding" refers to the situation in which a baby is given only breast-milk with no supplementary food (although medicines and vitamins, if needed, conform to the definition). While it is estimated that an average of 32 percent of women around the world who exclusively breastfeed will do so for up to six months, the proportion of Indonesian mothers who exclusively breastfeed is substantially less than that figure. It fluctuates from below 20 percent to less than 10 percent since 1991(Statistics Indonesia and Macro International 2008). These very modest figures suggest that devising a strategy to increase the proportion of women who provide six months exclusive breastfeeding could make a valuable contribution to Indonesian's public health. In addition, a better understanding of the impact of health message framing in gen- 
eral could contribute to public health efforts both there and elsewhere.

These gaps in our knowledge provide justification for research that replicates and extends prior studies in order to gain a deeper understanding of how to best structure persuasive communications used for social marketing promotions in alternative settings.

Based on the recognized research issues, this study aims to determine the effect of message framing and source credibility on the attitude and intention to provide six months exclusive breastfeeding. In addition, this study also looks in detail at the relationship between attitude and intention. The results of this study are expected to contribute to both academic and practical perspectives. For the academic perspective, this study will provide an understanding about the effect of message framing and source credibility on the attitude and intention of people in the context of breastfeeding behavior. For the practical perspective, this study will be the guidelines for social marketers and health practitioners to create a breastfeeding promotional campaign.

\section{Research Model and Hypotheses}

Social marketing has been recognized as an important approach to formulate strategies to change health behavior (Secker et al. 1995). In terms of promoting new behavior, marketing communication is an important component of social marketing (Alden et al. 2011). In the general context of social marketing promotion strategy, social communications play an important role in describing the actions which the target audience should do, and in telling them the benefits of adopt- ing the desired behavior (Keller and Thackeray 2011).

Alden et al. (2011) suggest that social marketing is different from ordinary health education. Parkinson et.al. (2011) argue that current breastfeeding promotions do not have any effect in motivating women to breastfeed. In particular, they explain that people already have knowledge about breastfeeding and its consequences. Hence, ordinary health education is not enough to influence individuals, to carry out this particular behavior.

In order to promote new health behavior, social marketers rely on promotion (Kotler and Lee 2008). Specifically, promotion includes both the design and the delivery of persuasive communication in terms of inspiring the target market to take a particular action. Stubblefield (1997) identifies two factors that seem to be particularly related to persuasive messages, namely the characteristics of the source and the characteristics of the message. Source factors relate to the person or organization responsible for the message and its distribution; meanwhile, message factors relate to the characteristics of the information itself.

Several studies have shown that framed messages have a significant effect on behavior change (Abhyankar et al. 2008; Banks et al. 1995; Rivers et al. 2005). With specific regard to influencing health behavior, paying attention to how a message is framed has been shown to be effective for altering attitudes and subsequent behavior (Levin et al. 1998; Rothman and Salovey 1997; Rothman et al. 2006). In recognition of this, the manipulation of message framing has been widely utilized in social marketing efforts.

The effect of message framing on peoples attitudes and intentions can be ex- 
plained by the Prospect Theory (Tversky and Kahneman 1981). The Prospect Theory argues that people set an expected outcome as a reference point. Any outcome beyond this reference point is considered a gain; and anything less is viewed as a loss. The certainty of realizing an outcome increases the degree to which people will seek to avoid a loss and increases how attractive a gain is perceived to be (Kahneman and Tversky 1979). Therefore, a persuasive message being framed either in terms of gains or losses should be relevant to the preferences for a range of behaviors. With the present focus, where a specific behavior -breastfeeding- is the focus, the following hypotheses can be generated:

$H_{1}$ : Message framing has an impact on an individual's attitude toward breastfeeding.

$\mathrm{H}_{2}$ : Message framing has an impact on an individual's intention to engage in breastfeeding.

Researchers have also shown that the influential effect of a message on an individual's attitudes and intentions is moderated by the credibility of the message source (Arora and Arora 2004; Jones et al. 2003; Jones et al. 2004). The current study uses the Elaboration Likelihood Model (ELM) proposed by Petty and Cacioppo (1986) as a basis for examining the moderating effect of source credibility on, first, the relationship between message framing and attitude, and second, between message framing and intention. The ELM explains that, under low elaboration conditions, receiving information from a credible source would be likely to provide a cognitively easier route to accept the information given in a message. In other words, if someone trusts the source and easily understands the facts of the issue, there is little need to more thoroughly elaborate on, or debate, the contentions made in a message. Given that breastfeeding is a natural be- havior with widely recognized benefits, it is classified in this study as low elaboration behavior.

In terms of the interaction between message framing and source credibility, Olson and Zanna (1993) suggested that the combination of a positively-framed message with a highly credible source will be the most effective combination in promoting low elaboration behavior. Therefore, the credibility of the message source should moderate the persuasiveness of the message on an individual's attitude and intention to provide exclusive breastfeeding. Thus we propose that:

$H_{3}$ : There is a significant interaction effect between message framing and source credibility on the attitude to provide exclusive breastfeeding.

Given that breastfeeding is likely to be a low elaboration behavior, as argued above, we expect that a positively-framed message with a high credibility source will be the most effective combination for affecting people's attitude.

\section{$H_{4}$ : There is a significant interaction effect between message framing and source credibility on the intention to provide exclusive breastfeeding.}

Recognizing the linkage between attitudes and intentions, we expect that a positively-framed message with a high credibility source will be the most effective combination for affecting people's intentions.

Several theories argue that attitudes exhibit strong influence on, and thus can be used to predict, intention. These perspectives include the Theory of Planned Behavior (TPB) (Ajzen 1991), the Theory of Reasoned Action (TRA) (Ajzen and Fishbein 1980) and the Triandis Model (Triandis 1977). Ajzen and Fishbein (1980) enhance the potential of these theories by linking intention with behavior which is, ultimately, a key outcome 
Figure 1. The Research Model

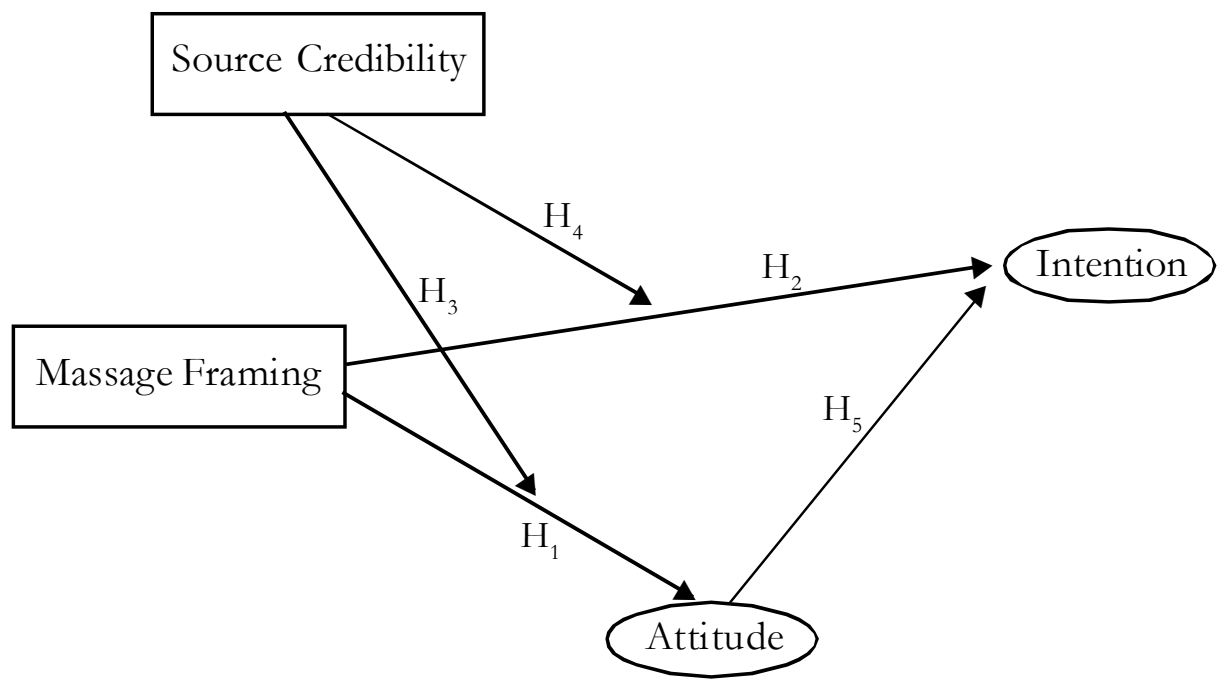

for social marketing efforts. In the realm of breastfeeding behavior, the hypothesized relationship between attitudes and intention has been confirmed through empirical work (Duckett et al. 1998; Wambach 1997). Thus it is proposed that:

$H_{5}$ : Attitude has an effect on a woman's intention to exclusively breastfeed.

These five hypotheses are graphically represented as Figure 1.

\section{Methods}

\section{Sample}

The sample of this study is pregnant woman. The selection of the group of pregnant women was based on the argument stating that the decision to start breastfeeding is usually made during pregnancy (Kramer et al. 2001; Martens and Young 1997). Furthermore, prior studies have shown that interven- tions such as peer support and health education during pregnancy will increase the likelihood of providing breastfeeding (Dyson et al. 2005; Ryan 1997).

The study relied on a convenience sample drawn from a variety of locations. Participants were recruited via a face-to-face request made in several maternity hospitals, obstetrician clinics, and breastfeeding workshops located in Malang, East Java Province, Indonesia. Three hundred and twenty questionnaires were distributed. Of these, 279 were completed, yielding a response rate of 87 percent.

The following demographic profile emerged from the sample: 68.1 percent of the respondents are aged between 21 to 30 years, 60.1 percent have completed a tertiary degree, 54.8 percent are working mothers, and 54 percent have more than one child. Table 1 presents the respondent's demographics information. 
Table 1. Demographic of Sample Population

\begin{tabular}{lcr}
\hline \multicolumn{1}{c}{ Variable } & Category & \% \\
\hline Age & Younger than 20 & 2.9 \\
& $21-30$ & 68.1 \\
& $31-40$ & 27.6 \\
& $41-50$ & 1.1 \\
Education & High school graduate or less & 36.9 \\
& Diploma & 16.8 \\
& Bachelor's & 40.1 \\
Job & Master's & 3.2 \\
& Working & 54.8 \\
Number of Children (including in utero) & Not Working & 43 \\
& 1 & 46 \\
& 2 & 39.1 \\
& 3 & 12.5 \\
& 4 & 0.7 \\
\hline
\end{tabular}

\section{Questionnaire Development}

Measures of attitudes and behavioral intentions were generated from the basic contentions of the Theory of Planned Behavior (Ajzen 1991; Duckett et al. 1998). The attitude toward exclusive breastfeeding was measured by six items using seven-point semantic differential scales. The scales utilized end points of weak - strong, unpersuasive - persuasive, unimportant - important, unbelievable - believable, uninformative - informative, not convincing - convincing, and bad argument-good argument. Three seven-point Likert scales were employed to measure the intention to exclusively breastfeed.

\section{Design and Procedures}

A $2 \times 2$ factorial design was used to measure the influence of message framing and source credibility on a woman's intention to breastfeed. Since the design consists of four factors, each discrete possible value and all experimental units take on all possible combinations of these levels across all such factors; the factorial design prepared in this study is considered as a full factorial experiment.

Four different advertising pamphlets were designed to provide the unique combinations of positive and negative framing as well as low and high source credibility. Ma- 
nipulation of the positively-framed message was done by presenting arguments that outlined the gains/benefits to be derived from breastfeeding. In contrast, the negatively

Table 2. Message Framing Manipulation framed message identified the benefits lost by not engaging in the behavior. Table 2 summarizes the framing manipulation used in this study.
Positively Framed Message

...that supplying exclusive breastfeeding for the first six months -with continued breastfeeding for the first year, provides several benefits for both baby and mother.

For baby:

- Potentially save 1.3 million lives

- Containing all the vitamins and minerals needed by a young baby

- Increasing the level of antibodies

- Reducing the chance of infection

- Build a health digestion system

For mother:

- Spacing pregnancies

- Reducing the chance to get ovarian cancer

- Decreasing the risk of breast cancer

- Economically cheaper than bottle feeding

... a baby will have more chance of being healthy and strong and the mother will have more chance of avoiding many health problems.

Six months exclusive breastfeeding provides many health benefits compared with providing bottle-feeding or other solid and liquid food.
Negatively Framed Message

...reported that not providing exclusive breastfeeding for the first six months with continued breastfeeding for the first year could potentially result in several disadvantages for both baby and mother.

For baby:

- Potentially lead to 1.3 million deaths every year

- Less chance to receive complete nutrition, vitamins and minerals

- Less effective antibodies

- Increasing the chance of getting infection

- Weakening the digestive system

For mother:

- Less chance to space pregnancies

- Having more potential to get ovarian cancer

- More likely to get breast cancer

- Economically more expensive than breastfeeding

... a baby will have less chance of being healthy and strong and the mother will have less ability to avoid many health problems.

Providing bottle-feeding or other solid and liquid food potentially will not provide as many benefits as six months exclusive breastfeeding. 
Table 3. Source Credibility Manipulation

\section{High Credibility Source}

By: Dr Ana Sofiyanti, M.Kes., Ph.D., SPA (Kons)

\section{Low Credibility Source}

By: Ana Sofiyanti

Undergraduate Student Faculty

of EconomicsJaya Manggala

University Jakarta
Regarding the message credibility variable, the high credibility message was presented by a (fictitious) breastfeeding expert and also included a logo designed to represent a breastfeeding-based organization, while the low credibility message was signed by a university student and did not appear with any organization's logo.

The research stimulus was in the form of a booklet, which contained instructions and information relating to the study, message stimuli, and a questionnaire.

To begin the experiment, an information sheet was distributed when the potential participants arrived at the registration desk. After reading the information sheet and agreeing to participate, the participants were given brief instructions, asking them to read the article and complete the attached questionnaire. The participants were given one of the four randomly selected stimulus messages. Reading the article and completing the questionnaire took participants from 15 to 20 minutes. During the experimental session, participants were allowed to stop at any time. In addition, participants were allowed to ask the experimenter for assistance if they had any difficulties in reading and understanding either the message stimulus or the questionnaire.

\section{Data Analysis}

Partial Least Square regression (PLS) was used to analyze the data and test the hypotheses. Specifically, Smart PLS with a bootstrapping re-sampling procedure was employed. PLS was used since this technique can handle both formative and reflective indicators. In this study, framing and credibility are the formative indicators, while attitude and intention are the reflective indicators. Furthermore, the ability of PLS to analyze data which have non-normal distributions is another advantage. Finally, PLS has the ability to control measurement error and can enhance testing of nomological webs among multiple dependent variables. PLS thus is able to contribute to an improved experimental research analysis in social sciences (Streukens et al. 2010).

For this study, to model the experimental data with the framework of a structural equation, single indicators for the manipulated factors, namely, message framing and source credibility as well as the interaction effect are specified. These manipulations utilize effect coding, such as a positively-framed message is coded as 1 , and a negativelyframed message as 0 , and a highly credible source is coded as 1 , and a low credible source 
as 0 . Since the manipulations do not have the typical properties of a reflective scale and it is assumed that the manipulation itself is measured without error, this study depicts the manipulations as formative indicators. While the manipulations are represented as formative indicators, the dependent variables - attitude and intention are represented as reflective indicators.

\section{Manipulation Checks}

Two tests examined whether the stimuli had anyimpact on perceptions. The first measured the manipulation of credibility. Participants were asked to rate the two versions of the message on six seven-point semantic differential scales, with the end points being trustworthy - not trustworthy, open minded -not open minded, good -bad, expert - not expert, experienced -not experienced, and trained -not trained. The mean difference be- tween the high credibility source (HC) and low credibility source $(\mathrm{LC})$, where mean $\mathrm{HC}_{\mathrm{HC}}=$ 6.29 and mean $_{\mathrm{LC}}=4.13$, was significant $(\mathrm{p}<$ $.001)$, indicating that the intended difference in the message source's credibility level was perceived by the respondents.

A seven-point semantic differential was also used to measure the framing stimuli. This used end-points of positive - negative to rate perceptions on how the message was framed. The comparison of the mean scores of the positively-framed message $\left(\right.$ mean $_{\mathrm{PF}}=6.78$ ) and negatively-framed message $\left(\right.$ mean $_{\mathrm{NF}}=$ 3.78), yielded a significant difference $(\mathrm{p}<$ .001). This demonstrated that the two frames were perceived as different by the sample.

\section{Results}

Before testing the hypotheses, it begins with reliability, convergent validity and discriminant validity checks. Table 4 provides

Table 4. Construct Loadings

\begin{tabular}{|c|c|c|}
\hline & Code & $\begin{array}{l}\text { Factor } \\
\text { Loading }\end{array}$ \\
\hline \multicolumn{3}{|l|}{$\overline{\text { Attitude }}$} \\
\hline Unpleasant/Pleasant & Atd_1 & 0.751 \\
\hline Embarrassing/Not embarrassing & Atd_2 & 0.817 \\
\hline Unhealthy/Healthy & Atd_3 & 0.801 \\
\hline Repulsive/Appealing & Atd_4 & 0.762 \\
\hline Inconvenient/Convenient & Atd_5 & 0.799 \\
\hline Unnatural/Natural & Atd_6 & 0.758 \\
\hline \multicolumn{3}{|l|}{ Intention } \\
\hline I expect... & Int_1 & 0.751 \\
\hline I want... & Int_2 & 0.789 \\
\hline I intend... & Int_3 & 0.729 \\
\hline
\end{tabular}


the PLS parameter estimates for the measurement model. The factor loadings for all scales are acceptable, indicating robust measures.

Table 5 explains the measures for examining internal consistency of a given block of indicators based on composite reliability (Hair et al. 2010) and Average Variance Extracted (AVE) (Fornell and Larcker 1981). The composite reliability for the constructs tested exceed the cut-off value of 0.70 proposed by Nunnally (1978). The AVE for the constructs also exceeds the cut-off value of 0.50 suggested by Fornell and Larcker (1981).

Following Chin's (1998) guidelines, two methods were used to check discriminant validity. The first was to compare the factor loadings and cross loadings. To avoid having a discriminant validity problem, the factor loading coefficients should be higher than their respective cross loadings. Table 5 indicates that the value of factor loadings for each construct is higher than the value of its respective cross loading. The second method was to compare the value of square root of AVE with the inter-correlation between constructs. Table 5 shows that the value of square root of AVE is higher than the intercorrelation among the constructs. Based on these outer model evaluations, it can be said that the measures used in this study are robust.
With the outer model assessment indicating robust measures, we then tested the hypotheses. Findings indicate that message framing does not have a significant main effect on either attitude $(t=1.534, p>0.05)$, or intention $(\mathrm{t}=1.424, \mathrm{p}>0.05)$. This leads to the rejection of both Hypotheses 1 and 2 .

In terms of moderating effects, it was found that the source credibility significantly moderates the effect of message framing on attitude $(\mathrm{t}=12.602, \mathrm{p}<0.01)$. This result supports Hypothesis 3. Since there is a significant interaction effect between message framing and source credibility on attitude, Analysis of Variance (ANOVA) was used to investigate the nature of this interaction. Analysis indicates that the Estimated Marginal Mean (EMM) of a positively-framed message coupled with a high source credibility is the highest $(E M M=5.756)$ compared to other framing and source credibility combinations (positively-framed message with low source credibility EMM $=5.236$, negatively-framed message with high credibility source $\mathrm{EMM}=5.155$ and negatively-framed message with low credibility source EMM= 5.671). Thus, in terms of influencing women's attitudes to provide six months of exclusive breastfeeding, a positively-framed message coming from a highly credible source is the most effective combination. However,

Table 5. Composite Reliability, AVE and Correlation among Constructs

\begin{tabular}{lllll}
\hline & AVE & $\begin{array}{l}\text { Composite } \\
\text { Reliability }\end{array}$ & Intention & Attitude \\
\cline { 4 - 5 } & 0.573 & 0.801 & 0.756 & \\
Intention & 0.611 & 0.904 & 0.696 & 0.781 \\
Attitude & & &
\end{tabular}


it is noteworthy that the combination of the negatively-framed message with the low credibility source yielded an EEM impact on attitude that was not substantially different from the positive-framed message, high credibility source EEM (5.756 versus 5.671).
The significant moderating effect of source credibility was also found in the relationship between message framing and intention $(\mathrm{t}=3,079 ; \mathrm{p}<0.01)$, supporting Hypothesis 4. ANOVA was again used to determine the nature of the interaction, with outcomes

Figure 2. Interaction between Framing and Source Credibility on Attitude and Intention

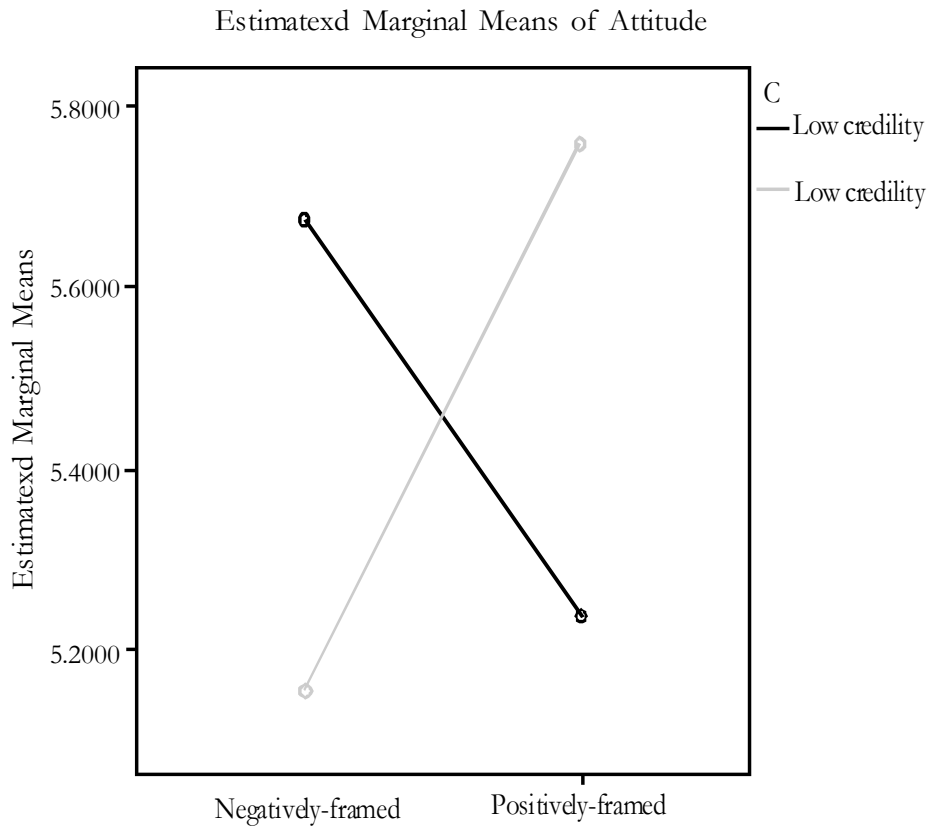

Estimatexd Marginal Means of Intention

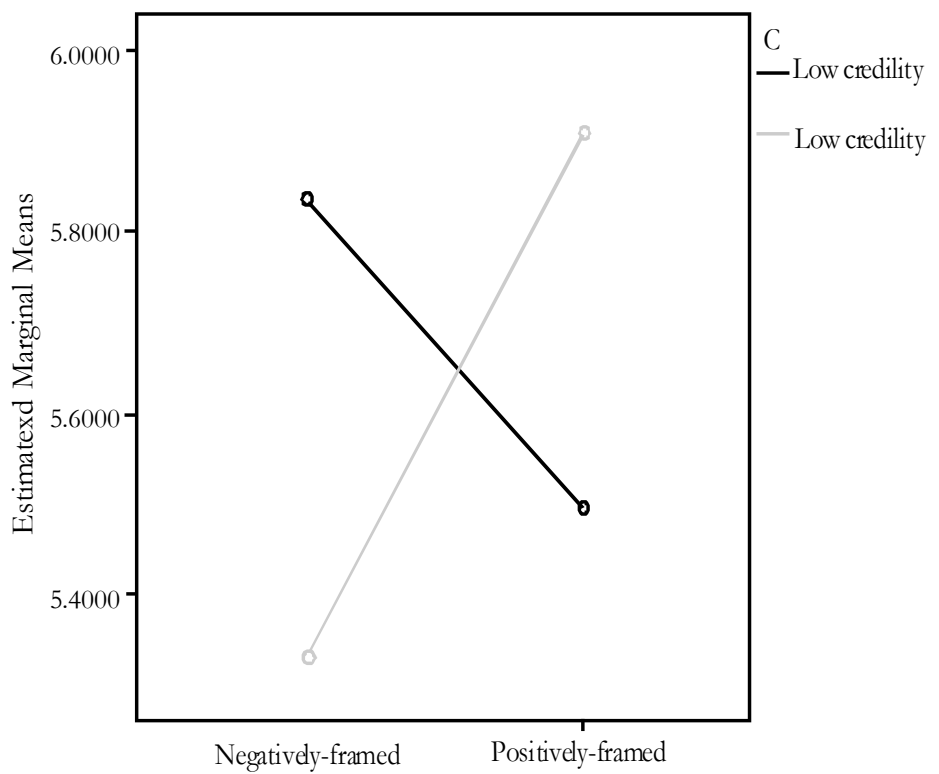


indicating that a positively-framed message coming from a relatively high credibility source was the most effective combination in affecting intention. The value of the EMM for this combination (5.910) is the largest among the other combinations (positivelyframed message and low credibility source $\mathrm{EMM}=5.497$, negatively-framed message and high-credibility source EMM= 5.333 and negatively-framed and low credibility source $\mathrm{EMM}=5.835$ ). As with the framing question results described above, the contrast between the impacts of the positive-frame with high credibility and negative-frame and low credibility on intention were of comparable magnitudes (5.910 versus 5.835). Figure 2 depicts the interaction effect of message framing and source credibility on attitude and intention.

Hypothesis 5's proposition that there is a significant effect of attitude on intention was supported by the data $(\mathrm{t}=12.782 ; \mathrm{p}<$ $0.01, \beta=0.615)$. Attitude was shown to positively influence intention; the more positive the attitude of women toward providing six months of exclusive breastfeeding, the higher their intention to exclusively breastfeed.

Referring to the coefficient of determination $\left(\mathrm{R}^{2}\right)$, message framing and the interaction of message framing and credibility explains roughly a quarter $(24.6 \%)$ of the variance in attitude. In addition, 50.8 percent of the variance in intention was explained by attitude, message framing and the interaction of message framing and source credibility. Table 6 summarizes the results of the hypotheses testing.

To ensure the robustness of the research model, this study also uses the Goodness of Fit $(\mathrm{GoF})$ index. Since PLS is a variancebased SEM, it does not have a formal GoF. Therefore, the calculation of GoF refers to Tenenhaus et al's. (2004) suggestion. Derived from Tenenhaus et al. (2004), Daryanto et al. (2010) proposed that the baselines for GoF are $\operatorname{small}=0.1$, medium $=0.25$ and large $=$ 0.36.The GoF for this study (0.471) is quite robust.

Table 6. Hypotheses Testing Summary

\begin{tabular}{clrl}
\hline Hypothesis & & Path & t-value \\
\hline H1 & Message Framing $\rightarrow$ Attitude & 1.534 & NS \\
H2 & Message Framing $\rightarrow$ Intention & 1.424 & NS \\
H3 & MF $*$ SC $\rightarrow$ Attitude & $12.602 *$ & Supported \\
H4 & MF $*$ SC $\rightarrow$ Intention & $3.079 *$ & Supported \\
H5 & Attitude $\rightarrow$ Intention & $12.782 *$ & Supported \\
\hline
\end{tabular}




\section{Discussion}

The hypothesized direct relationships between 1) message framing and attitude, and 2) message framing and intention were not found. These results are inconsistent with those obtained in studies by Arora (2000, 2007) and Jones et al. (2004). The first possible explanation for this difference is centered on the nature of breastfeeding behavior. Many campaigns have been launched to promote exclusive breastfeeding behavior in Indonesia; for example, in 2010 UNICEF supported a mobile media-based advertising campaign to raise awareness of the benefits of exclusive breastfeeding for children. In addition, and with respect to demographic characteristics, around 54 percent of the current study's participants have more than one child, suggesting that breastfeeding and its related issues are not new to them. Thus, it is possible that this study's participants were already aware of the benefits of exclusive breastfeeding and, by recognizing those benefits, already had a positive attitude toward exclusive breastfeeding. These are attitudes which could have been formed through prior exposure to similar messages, personal experience or, perhaps, as a result of general societal support of the practice. Therefore, there is a possibility that any stimulus provided would not have had an incremental effect on previous favorable evaluations of the practice.

The belief that they and their children are certain to realize the benefits of breastfeeding is another possible explanation for the insignificant main effect of message framing on women's attitudes towards providing exclusive breastfeeding. If the arguments presented by the advertisement conform to already held attitudes, it is reasonable to expect little or no impact of framing on the attitude. The Prospect Theory (Kahneman and Tversky 1979) posits that for relatively low risk behaviors, gain-framed or positively-framed messages will be more persuasive than loss-or negatively-framed messages. Thus, low risk behaviors can be thought of as having little risk of not realizing the expected outcomes - that is, do this and these outcomes will occur. Alternatively, although breast milk has been clinically demonstrated to be the complete nutrition for infants (Galson 2008), it is possible that message framing alone was not enough to overcome the thought that the outcomes of adopting this behavior will vary between infants and mothers. In addition, because positive outcomes are not easy to discern, perhaps there is an underlying concern that they will not be attained.

Yet, when the positively-framed message is delivered by a credible source, there are differences found in both the attitudes towards exclusive breastfeeding and the intention to engage in exclusive breastfeeding. Perhaps while framing alone cannot dispel perceptions of risk, the addition of a credible message source may lower to a degree the possible uncertainty that positive outcomes will be achieved and, consistent with the tenets of ELM, make the message easier to internalize.

Framing alone does not establish the type of connection with the target audience that framing in conjunction with a credible message source appears to provide. If the focus is shifted from the effect of external stimuli, such as an advertisement that could be used in a social marketing campaign, and looks instead at the psychology behind the motivation, or intention, to engage in a certain behavior, the Theory of Planned Behavior (TPB) can be used as a basis to understand this study's findings. Based on the TPB 
(Ajzen 1991), an individual's intention to adopt a desired behavior was affected by three robust variables; attitudes, perceived behavioral control (PBC) and subjective norms. In accordance to the TPB approach and several studies in the area of breastfeeding behavior (Dodgson et al. 2003; Duckett et al. 1998; Wambach 1997), this study found that the women's favorable attitude toward providing exclusive breastfeeding has a significant positive effect on their intention to exclusively breastfeed. This attitude is unlikely to be something formed by one exposure to an advertisement, but rather it is formed over time and with repeated exposure to the stimulus, or as a result of different sources of influence pointing to the same basic evaluation. Advertising can certainly serve as one of those sources in a larger social marketing campaign.

Based on the research findings, the most significant theoretical contribution of this research is the extension of the body of knowledge by integrating ELM and the Prospect Theory in investigating the effect of message framing and source credibility on behavioral intention and attitude in the area of social marketing. Specifically, the present study provides a comprehensive evaluation of the effect of message framing and the moderating effect of source credibility on an individual's attitude and intention to provide exclusive breastfeeding behavior. This study validates previous studies such as Abhyankar et al.(2008), Jones et al.(2004) and O'Connor et al. (2005), who found that message framing does not have a significant main effect on behavioral intention and attitude. Meanwhile, this study challenges the findings of Jones et al. (2004) who investigated the effect of message framing and source credibility on behavioral intention and its predictors. While Jones' study did not find significant interaction effect between message framing and source credibility on behavioral intention and other socio-cognitive variables, this research found a significant interaction effect where a positively-framed message coming from a high credibility source was the most effective combination in influencing behavioral intention and attitude. The combination of a positively-framed message which comes from a highly credible source supports the prediction of the Prospect Theory (Kahneman and Tversky 1979), which suggested that an individual will avoid risk in the domain of gains, and the ELM (Petty and Cacioppo 1986) which claimed that under the low elaboration condition, a high credibility source will be more persuasive than a low credibility source.

\section{Limitations and Recommendations}

The primary limitation of this study is that it does not measure the actual behavior of interest; instead, it only measures the intention of women to exclusively breastfeed. This limitation is common to many studies utilizing intention as a dependant construct. It is recommended that a future study could move beyond measurement of this behavioral proxy and could include a measure of actual behavior. Another limitation is in regard to the sample recruitment. While this study obtained a relatively large sample $(n=279)$, respondents were pregnant mothers recruited during a brief time span from several hospitals, maternity clinics and breastfeeding workshops in Malang, Indonesia. Hence the sample does not represent the population of pregnant Indonesians and the findings thus may not be generalized to either non-pregnant mothers or pregnant women in other places. Finally, since this study only investigated the 
direct relationships among constructs, any future study could also investigate indirect relationships to provide more comprehensive knowledge about persuasive communication, message framing, source credibility and behavioral change.

\section{References}

Abhyankar, P., D. B. O'Connor, and R. Lawton. 2008. The role of message framing in promoting MMR vaccination: Evidence of a loss-frame advantage. Psychology, Health and Medicine 13 (1): 1.

Ajzen, I. 1991. The theory of planned behavior. Organizational Behavior and Human Decission Process 50: 179211.

Ajzen, I., and M. Fishbein. 1980. Understanding Attitudes and Predicting Social Behavior. Prentice-Hall.

Alden, D. L., M. D. Basil, and S. Deshpande. 2011. Communications in social marketing. In G. Hastings, K. Angus, and C. A. Bryant (Eds.), The SAGE Handbook of Social Marketing. London: SAGE Publications Ltd.

Arora, R. 2000. Message framing and credibility: application in dental services. Health Marketing Quarterly 18 (1-2): 29.

Arora, R. 2007. Message framing strategies for new and mature products. Journal of Product and Brand Management 16 (6): 377-385.

Arora, R., and A. Arora. 2004. The impact of message framing and credibility. Service Marketing Quarterly 26 (1): $35-53$.

Arora, R., C. Stoner, and A. Arora. 2006. Using framing and credibility to incorporate exercise and fitness in individuals' lifestyle. Journal of Consumer Marketing 23 (4): 199 - 207.

Banks, S. M., P. Salovey, S. Greener, A. J. Rothman, A. Moyer, J. Beauvais, and E. Epel. 1995. The effects of message framing on mammography utilization. Health Psychology 14: 178-178.

Daryanto, A., K. de Ruyter, and M. Wetzels. 2010. Getting a discount or sharing the cost: The influence of regulatory fit on consumer response to service pricing schemes. Journal of Service Research 13 (2): 153-167.

Dodgson, J. E., S. J. Henly, L. Duckett, and M. Tarrant. 2003. Theory of planned behavior-based models for breastfeeding duration among Hong Kong mothers. Nursing Research 52 (3): 148.

Duckett, L., S. Henly, M. Avery, S. Potter, S. Hills-Bonczyk, R. Hulden, and K. Savik. 1998. A theory of planned behavior-based structural model for breast-feeding. Nursing Research 47 (6).

Dyson, L., F. McCormick, and M. J. Renfrew. 2005. Interventions for promoting the initiation of breastfeeding. Cochrane Database Syst Rev 2.

Fornell, C., and D. F. Larcker. 1981. Evaluating structural equation models with unobservable variables and measurement error. Journal of Marketing research 18 (1): 39-50.

Galson, S. K. (R. A.). 2008. Mothers and children benefit from breastfeeding. Journal of the American Dietetic Association 108 (7): 1106 - 1107.

Hair, J. F., W. C. Black, B. J. Babin, and D. R. Anderson. 2010. Multivariate Data Analysis: A Global Perspective ( $7^{\text {th }}$ ed.). Upper Saddle River: Pearson Education Inc. 
Jones, L. W., R. C. Sinclair, and K. S. Courneva. 2003. The effects of source credibility and message framing on exercise intentions, behaviors and attitudes: An integration of the elaboration likelihood model and prospect theory. Journal of Applied Social Psychology, 33(1), 179 - 196.

Jones, L. W., Sinclair, R. C., Rhodes, R. E., and Courneya, K. S. (2004). Promoting exercise behaviour: an integration of persuasion theories and the theory of planned behaviour. British journal of health psychology, 9(4), 505-521.

Kahneman, D., and A. Tversky. 1979. Prospect theory: An analysis of decision under risk. Econometrica: Journal of the Econometric Society: 263-291.

Keller, H., and R. Thackeray. 2011. Social marketing and the creative process. Health Promotion Practice 12 (5): 651-653.

Kim, S.-B., and D-Y. Kim. 2014. The effects of message framing and source credibility on green messages in hotels. Cornell Hospitality Quarterly 55 (1): 64-75.

Kotler, P., and N. R. Lee. 2008. Social Marketing: Influencing Behaviors for Good (3 ${ }^{\text {rd }}$ ed.). Thousan Oaks: Sage Publications.

Kramer, M. S., B. Chalmers, E. D. Hodnett, Z. Sevkovskaya, I. Dzikovich, S. Shapiro, J. P. Collet, I. Vanilovich, I. Mezen, and T. Ducruet. 2001. Promotion of breastfeeding intervention trial (PROBIT). JAMA: the journal of the American Medical Association 285 (4): 413-420.

Kumkale, G. T., D. Albarracín, and P. J. Seignourel. 2010. The effects of source credibility in the presence or absence of prior attitudes: Implications for the design of persuasive communication campaigns. Journal of Applied Social Psychology 40 (6): 1325-1356.

Levin, I. P., S. L. Schneider, and G. J. Gaeth. 1998. All frames are not created equal: A typology and critical analysis of framing effects. Organizational Behavior and Human Decision Processes 76 (2): 149-188.

Martens, P. J., and T. K. Young. 1997. Determinants of breastfeeding in four Canadian Ojibwa communities: A decision making model. American Journal of Human Biology 9 (5): 579-593.

Nunnally, J. 1978. Pyschometric Theory. New York: McGraw-Hill.

O'Connor, D. B., E. Ferguson, and R. C. O'Connor. 2005. Intentions to use hormonal male contraception: The role of message framing, attitudes and stress appraisals. British Journal of Psychology 96 (3): 351-369.

O'Keefe, D. J., and J. D. Jensen. 2007. The relative persuasiveness of gain-framed loss-framed messages for encouraging disease prevention behaviors: A meta-analytic review. Journal of Health Communication 12 (7): 623 - 644 .

Olson, J. M., and M. P. Zanna. 1993. Attitudes and attitude change. Annual Review of Psychology 44 (1): 117154.

Parkinson, J., R. Russell-Bennett, and J. Previte. 2011. Mum or bub? Which influences breastfeeding loyalty. Australasian Marketing Journal (AMJ).

Petty, R. E., and J. T. Cacioppo. 1986. The elaboration likelihood model of persuasion. Advances in experimental social psychology 19 (1): 123-205.

Rivers, S. E., P. Salovey, D. A. Pizarro, J. Pizarro, and T. R. Schneider. 2005. Message framing and pap test utilization among women attending a community health clinic. Journal of Health Psychology 10 (1): 65.

Rothman, A. J., and P. Salovey. 1997. Shaping perception to motivate healthy behavior: The role of message framing. Psychological Bulleting 121 (1): 3 - 19. 
Rothman, A. J., R. D. Bartels, J. Wlaschin, and P. Salovey. 2006. The strategic use of gain-and loss-framed messages to promote healthy behavior: How theory can inform practice. Journal of Communication 56 (s1): 202-220.

Rothman, A. J., P. Salovey, C. Antone, K. Keough, and C. D. Martin. 1993. The influence of message framing on intentions to perform health behaviors. Journal of Experimental Social Psychology 29 (5): 408-433. doi:10.1006/jesp.1993.1019

Ryan, A. S. 1997. The resurgence of breastfeeding in the United States. Pediatrics 99 (4): e12-e12.

Secker, J., E. Wimbush, J. Watson, and K. Milburn. 1995. Qualitative methods in health promotion research: some criteria for quality. Health Education Journal 54 (1): 74.

Statistics Indonesia, and Macro International. 2008. Indonesia Demographic and Health Survey 2007. Maryland: BPS and Macro International.

Streukens, S., M. Wetzels, A. Daryanto, and K. De Ruyter. 2010. Analyzing factorial experimental data using PLS: An alternative approach and application in an online complaining context. In V. EspositoVinzi, W. Chin, J. Henseler and H. Wand (Eds.), Handbook of Partial Least Squares: Concepts, Methods and Applications: Springer.

Stubblefield, C. 1997. Persuasive communication: Marketing health promotion. Nursing Outlook 45: 173 177.

Tenenhaus, M., S. Amato, and V. Esposito Vinzi. 2004. A global goodness-of-fit index for PLS structural equation modelling. Paper presented at the Proceedings of the XLII SIS scientific meeting.

Triandis, H. C. 1977. Interpersonal behavior: Brooks/Cole Pub. Co.

Tversky, A., and D. Kahneman. 1981. The framing of decisions and the psychology of choice. Science, 211 (4481): 453.

Wambach, K. A. 1997. Breastfeeding intention and outcome: A test of the theory of planned behavior. Research in Nursing and Health 20 (1): 51-60.

Zhang, Y., and R. Buda. 1999. Moderating fffects of need for cognition on responses to positively versus negatively framed advertising messages. Journal of Advertising 28 (2): 1-15. 
